\title{
Addison's disease and diffuse cerebral sclerosis
}

\author{
ANNE M. GRAY \\ From the Department of Psychological Medicine, Eastern District Hospital. \\ Glasgow
}

The rare combination of Addison's disease and diffuse cerebral sclerosis is now recognized to be something more than coincidence. Although only a small number of cases have been reported up to date, those cases have all followed a very similar pattern. This paper presents the case of a patient who is still alive and in whom, therefore, the diagnosis of diffuse cerebral sclerosis has not been confirmed histologically. The diagnosis of Addison's disease, however, has been confirmed beyond all doubt, and there is a positive family history for diffuse cerebral sclerosis.

\section{CASE HISTORY}

R. D., a 26-year-old shipyard worker, presented himself at hospital on 27 January 1967, complaining of staggering and dragging of the left leg of three weeks' duration. He was admitted to a medical unit and later transferred to a psychiatric unit because his disinhibited behaviour made treatment in a general medical ward unsuitable. On admission a generalized hyperpigmentation was noted, with marked oral pigmentation. He walked on a wide base and was seen to stagger at times, although with care he could walk fairly steadily. Co-ordination in the lower limbs was impaired on both sides, and all the tendon reflexes were brisk, especially in the left leg. There was a bilateral extensor plantar response. There was no sensory or motor deficit, and there were no ocular or ophthalmoscopic abnormalities. Blood pressure was $120 / 75 \mathrm{~mm} \mathrm{Hg}$, and no abnormality was found in any other system.

His early history was unremarkable. Delivery was normal and spontaneous, and all the milestones were normal. His performance at school was satisfactory and he was probably of good average intelligence. He showed no behavioural disturbance, and his work record was excellent until the age of 25 years, although he did not progress beyond unskilled work. The hyperpigmentation of his skin was first noticed at 19 years, but no history suggestive of adrenocortical deficiency could be elicited. His physical health was good and there was no history of serious illness. He married at the age of 22 and had a son in 1964, and a daughter in 1966.

At the age of 23 years there was a change in his behaviour. He became irresponsible in small matters, and

'Present Address: Department of Psychological Medicine, Southern General Hospital, Glasgow. this irresponsibility increased until, during the year immediately preceding admission to hospital, he was in trouble with the police on three occasions for stealing small articles of little value. This was quite out of character. Five months before admission he suddenly left the shipyard where he had worked for 10 years and moved to another, but he started to sleep late in the mornings and his attendance at work became irregular. In January 1967 he had an upper respiratory infection and began to complain of drowsiness and staggering. He eventually presented himself at hospital with this complaint.

FAMILY HISTORY The patient's father died in 1957 after a heart attack. His mother is alive and well. His eldes $\omega$ brother died in a psychiatric hospital in 1953 at the ag $\vec{A}$ of 20 years, and a post-mortem diagnosis of diffuse 응 cerebral sclerosis was made. There is a sister (b. 1931 . and a brother (b. 1939), both of whom are in goo $\square$ health. No other family history of psychiatric, neuro logical, or endocrine disease was found.

The patient's eldest brother had a normal childhood and was considered to be of average intelligence at schoo $\bar{c}$ When he was called up for military service at the age of o 18 years some deterioration must have taken place because he was placed in selection grade 4 . This deterioration continued until he became slovenly in his personal habits and was eventually unable to complete a task without constant supervision. He was admitted to hospital where no abnormal neurological signs were found, and a diagnosis of schizophrenia was made. He was given electroconvulsive therapy, but there wasno improvement and he was eventually sent home and later admitted to a psychiatric hospital in Glasgow. His mental condition deteriorated gradually but there were still no abnormal neurological signs. A year after admission the general deterioration was very marked and it was scarcely possible to engage his attention. He could not stand without support and there was a bilateral grasp reflex with forced groping. An extensor plantar reponse appeared on the right side and EEG showed a great deal $O$ of delta activity from the posterior parts of the brain. No diagnosis could be made during life, and he suddenly 윽 went into status epilepticus and died three hours later. $D$ Initial post-mortem findings showed nothing significant in the central nervous system, but a review requested a year later showed definite evidence of diffuse cerebral o sclerosis. A more recent review was reported on as follows: N 'It is a pity that we were unable to examine frozen sections from this case, but there is no doubt that it is $\omega$ 
basically one of diffuse cerebral sclerosis. In view of the similar disease now affecting a brother it seems likely that the correct diagnosis is a Sudanophil leucodystrophy, but this cannot be confirmed on the material available. I have, unfortunately, been able to establish that there are no blocks of adrenal glands available.' There were no notes in the records to suggest adrenal insufficiency, and this patient did not show hyperpigmentation.

CliniCAL INVESTIGATIONS Radiographs of chest, spine, long bones, and skull were negative. Haematology, ESR, serum electrolytes, liver function tests, and serum iron and iron binding capacity were normal. A Synacthen (corticotrophin) test showed a negative response to Synacthen and plasma cortisol levels (Mattingly method) were $4 \mu \mathrm{g} / 100 \mathrm{ml}$. (a.m.) and $6.5 \mu \mathrm{g} / 100 \mathrm{ml}$. (p.m.). ACTH assay showed high levels of more than $20 \mathrm{mu}$ / $100 \mathrm{ml}$. Cerebrospinal fluid showed a protein level of $90 \mathrm{mg} / 100 \mathrm{ml}$. and there was a weak mid-zone colloidal gold curve $(0012000000)$. Immunological tests were negative for antinuclear factor, adrenal antibody and antibrain antibody. Tests of thyroid function were normal. An EEG at this stage showed no abnormality. Electromyography showed no evidence of denervation of limb muscles. The conduction velocity of the left lateral popliteal nerve was $50 \mathrm{~m} / \mathrm{sec}$. Neuromuscular transmission was normal. Chromosome studies on the patient's blood showed no evidence of a sex chromosome abnormality and the karyotype analysis was within normal limits. Ophthalmological investigation showed no abnormality, and, in particular, there was no defect in colour vision.

MENTAL STATE The patient was disinhibited, emotionally labile, facile, distractable, and hyperkinetic. He had great difficulty in carrying on a normal conversation and his behaviour was noisy and interfering, although he was generally good-humoured. There was no sign indicative of a functional psychosis.

FUTHER INVESTIGATION OF ADRENOCORTICAL FUNCTION In May 1967 a 24-hour collection of urine was made under ACTH stimulation and during temporary suppression of steroid therapy, and the steroid excretion pattern of the patient was investigated. Normal excretion of cortisol metabolites was found with zero excretion of corticosterone metabolites. No extra steroids were found in the groups studied ( 21 groups).

PROGRESS Since the patient was first seen there has been a gradual deterioration in his mental and physical state. An EEG in January 1968 showed a change in the dominant rhythm from $10 \mathrm{~Hz}$ to $9 \mathrm{~Hz}$ and there was a background of low voltage theta activity with occasional episodes of high voltage delta activity from the left side of the brain, mainly anteriorly. A further EEG in October 1968 showed continued deterioration with a good deal of widespread slow activity. Although his general health is satisfactory, he now has incontinence of urine every night and at times during the day. There is also faecal incontinence, mostly during the night but occasionally during the day. There has been no significant advance in the spastic signs. As far as his mental state is concerned, there has been some deterioration, in that he has less 4* insight and is more facile, emotionally labile, and disinhibited. He was transferred to a psychiatric hospital in January 1968.

\section{DISCUSSION}

Since Siemerling and Creutzfeldt first reported a case of Addison's disease with diffuse cerebral sclerosis in 1923, 12 other cases have been reported with post-mortem confirmation of both the endocrine and the neurological disorder (Table I). In five cases there was a positive family history for the neurological disease and in one case there was a positive family history for both the neurological disease and Addison's disease. All the patients were young males, and in most cases the onset of the Addison's disease preceded the onset of the neurological symptoms. In general, the Addison's disease was mild and suspected only because of the hyperpigmentation, although in some cases vomiting was also present. The neurological phase was ushered in by deterioration of intellect and behaviour and death occurred within six months to four years of the onset of this phase, the average period of survival being one year and eight months. Progression of the neurological disease was marked by ataxia and spasticity, culminating in a spastic tetraplegia. In a large proportion of the cases there was marked deterioration in vision leading, in some, to blindness before death.

The presence of a positive family history of diffuse cerebral sclerosis in five out of the 13 patients strongly supports the case for an X-chromosomal recessive mode of inheritance. It is less easy to account for the coexistence of the two disorders as a syndrome. Erbsloh (1958) considered that the adrenocortical atrophy might be secondary to the lesions of the brain, while Gagnon and Leblanc (1959) postulated the existence of a humoral factor necessary for the normal development of myelin and the maintenance of its integrity. Blaw, Osterberg, Kozak, and Nelson (1964) have suggested that the secretion of an abnormal steroid might be responsible for the neurological illness. At necropsy, marked cortical atrophy was found in the adrenals of the recorded cases of this syndrome, and no pituitary abnormality was found except in one case where there was also an interstitial cell tumour of one testis (Hoefnagel, Van Den Noort, and Ingbar, 1962). Steroid therapy did not affect the progress of the neurological disease in any case. This would argue against the case for the nervous system lesions being secondary to the adrenocortical hypofunction.

It is not easy to establish the date of onset of the neurological disease in a condition where the symptoms and signs are so ill defined. In the present 
TABLE I

ADDISON'S DISEASE AND DIFFUSE CEREBRAL SCLEROSIS ${ }^{1}$

\begin{tabular}{|c|c|c|c|c|c|}
\hline \multirow[t]{2}{*}{ Reference } & \multicolumn{2}{|c|}{ Addison's disease } & \multirow{2}{*}{$\begin{array}{c}\text { Onset of } \\
\text { neurological } \\
\text { disease }(y r)\end{array}$} & \multirow{2}{*}{$\begin{array}{c}\text { Age at } \\
\text { death } \\
(y r)\end{array}$} & \multirow{2}{*}{$\begin{array}{l}\text { Family history } \\
\text { of diffuse } \\
\text { cerebral sclerosi }\end{array}$} \\
\hline & Symptomatology & $\begin{array}{l}\text { Age at onset } \\
(y r)\end{array}$ & & & \\
\hline Siemerling and Creutzfeldt (1923) & Pigmentation & $3-4$ & $6 \frac{1}{2}$ & 7 & - \\
\hline Pfister (1936) & Pigmentation & 3 & 7 & $8 \frac{1}{2}$ & + \\
\hline Pfister (1936) & Pigmentation & $?$ & 9 & 10 & - \\
\hline Hampel (1937) & Pigmentation & 15 & $?$ & 23 & - \\
\hline Lichtenstein and Rosenbluth (1959) & Pigmentation & \pm 5 & \pm 5 & 7 & - \\
\hline Gagnon and Leblanc (1959) & Pigmentation & 7 & 9 & 10 & + \\
\hline Brun and Voigt (1960) & $\begin{array}{l}\text { Pigmentation } \\
\text { Vomiting }\end{array}$ & 9 & 9 & $10 \frac{3}{4}$ & - \\
\hline Hoefnagel et al. (1962) & None & $?$ & $5 \frac{1}{2}$ & 7 & - \\
\hline $\begin{array}{l}\text { Fanconi, Prader, Isler, Luthy } \\
\text { and Siebenmann (1963) }\end{array}$ & $\begin{array}{l}\text { Pigmentation } \\
\text { Vomiting }\end{array}$ & $14 \frac{1}{4}$ & $14 \frac{1}{2}$ & $17 \frac{1}{2}$ & - \\
\hline $\begin{array}{l}\text { Dubois, Loeb, Perier, } \\
\text { Parmentier, and Szliwowski (1964) }\end{array}$ & $\begin{array}{l}\text { Pigmentation } \\
\text { Vomiting }\end{array}$ & ? & $7-8$ & 10 & + \\
\hline Blaw et al. (1964) & $\begin{array}{l}\text { Pigmentation } \\
\text { Vomiting }\end{array}$ & $8 \frac{1}{2}$ & 9 & $9 \frac{3}{4}$ & + \\
\hline Turkington and Stempfel (1966) & $\begin{array}{l}\text { Pigmentation } \\
\text { Vomiting }\end{array}$ & 3 & 5 & $7 \frac{3}{4}$ & - \\
\hline $\begin{array}{c}\text { Hoefnagel, Brun, Ingbar, and } \\
\text { Goldman (1967) }\end{array}$ & Pigmentation & $7 \frac{1}{2}$ & 10 & $11 \frac{1}{4}$ & + \\
\hline Present case (1969) & Pigmentation & 19 & 25 & - & + \\
\hline
\end{tabular}

${ }^{1}$ All the cases listed above were male and in all there was post-mortem confirmation of both Addison's disease and diffuse cerebral sclerosis, with the exception of the present case in whom Addison's disease has been confirmed biochemically

case, the manifest neurological disease started at 25 years, but there is a history of a change in personality at 23 years. It could even be suggested that the neurological disease started considerably earlier, because it is unusual for a stable worker of good average intelligence to choose unskilled work. It is possible, therefore, that the neurological phase actually antedated the Addison's disease in this patient.

This case is incomplete because the diagnosis of diffuse cerebral sclerosis has not been confirmed histologically. The character and progress of the neurological disease, however, taken in conjunction with the family history, make such a diagnosis highly probable. There is direct electroencephalographic evidence of a progressive cerebral disorder, and the mental state of the patient pointed towards this diagnosis at an early stage of his illness when there was no electroencephalographic abnormality. Addison's disease has been confirmed in this patient, and steroid therapy has had no effect on the progress of the neurological disease.

This patient is considerably older than the other cases described, with the exception of the patient of Hampel (1937) who died at the age of 23 years. It is interesting to note that the psychiatric picture in this case is dominated by deterioration in behaviour and personality, whereas in the younger cases intellectual deterioration was more marked and, in addition, visual deterioration and motor paralyses were prominent.

Most of the cases previously described have died shortly after being seen and it has not been possible to do many investigations during their lifetime. I this case it has been possible to do chromosoma and immunological studies and, in addition, Blaw' theory of the production of an abnormal steroid ha£ been investigated. Unfortunately, none of those investigations has thrown any light on the problent of the coexistence of the two conditions.

It is significant that, out of the 13 cases of this syndrome which have been described, no less than nine have been described during the past 10 years. It is highly probable that many such cases are being missed. The Addison's disease is invariably mild in character and might easily be missed, and in an older patient the neurological phase is very likely to present as a psychiatric rather than a neurological problem. It is important, therefore, that psychiatrists should be aware of this syndrome.

\section{SUMMARY}

This paper describes a case of Addison's disease in conjunction with a progressive cerebral disorder in a patient with a positive family history for diffuse cerebral sclerosis. Chromosomal, steroid, and immunological investigations have given negative results apart from the confirmation of Addison's disease. This case is discussed in the context of cases of Addison's disease and diffuse cerebral sclerosis which have been reported in medical literature. It is suggested that cases might be missed because of the mode of onset of the neurological 
phase, making the problem appear psychiatric rather than neurological, and because of the mild nature of the Addison's disease.

I am indebted to Dr. James McHarg (Royal Dundee Liff Hospital, Dundee) for his notes and comments on the brother of this patient; Dr. J. Hume Adams (Department of Pathology, Western Infirmary, Glasgow) for the pathological report; Dr. J. K. Grant (Steroid Biochemistry Department, Glasgow Royal Infirmary) for advice and help in steroid investigations; Professor J. A. Simpson (Institute of Neurological Sciences, Glasgow) for neurological guidance and electrophysiological studies; Dr. W. G. Whyte (Glasgow Royal Infirmary) for endocrinological advice; and the Physician Superintendent and staff of Gartloch Hospital, Gartcosh, Glasgow, for their co-operation.

\section{REFERENCES}

Blaw, M. E., Osterberg, K., Kozak, P., and Nelson, E. (1964). Sudanophilic leukodystrophy and adrenal cortical atrophy. Arch. Neurol. (Chic.), 11, 626-631.

Brun, A., and Voigt, G. E. (1960). Entzundliche cerebrale Sklerose mit Nebenniereninsuffizienz. Dtsch. Z. Nervenheilk., 180, 654-664.
Dubois, R., Loeb, H., Perier, O., Parmentier, R., and Szliwowski, H. (1964). Maladie d'Addison et sclérose diffuse de Schilder. Helv. Paediat. Acta. 19, 528-555.

Erbsloh, F. (1958). P. 1740 in Handbuch der speziellen pathologischen Anatomie und Histologie, Vol. 13, pt. 23, Edited by F. Henke and $O$. Lubarsch. Springer, Berlin.

Fanconi, A., Prader, A., Isler, W., Luthy, F., and Siebenmann, R. (1963). Morbus Addison mit Hirnsklerose im Kindesalter. Ein hereditäres Syndrom mit X-chromosomaler Vererbung? Helv. Paediat. Acta., 18, 480-501.

Gagnon, J., and Leblanc, R. (1959). Sclérose cérébrale diffuse avec mélanodermie et atrophie surrénale. Un Méd. Can., 88, 392-412.

Hampel, E. (1937). Morbus Addisonii und sklerosierende Erkrankung des Hemispharenmarks. Dtsch. Z. Nervenheilk., 142, 186-208.

Hoefnagel, D., Van Den Noort, S., and Ingbar, S. H. (1962). Diffuse cerebral sclerosis with endocrine abnormalities in young males. Brain, 85, 553-568.

—, Brun, A., Ingbar, S. H., and Goldman, H. (1967). Addison's disease and diffuse cerebral sclerosis. J. Neurol. Neurosurg. Psychiat., 30, 56-60.

Lichtenstein, B. W., and Rosenbluth, P. R., (1959). Schilder's disease with melanoderma. J. Neuropath. exp. Neurol., 18, 384-396.

Pfister, R. (1936). Beitrag zur Kenntnis du diffusen Hirnsklerose. Arch. Psychiat. Nervenkr., 105, 1-16.

Siemerling, E., and Creutzfeldt, H. G. (1923). Bronzekrankheit und sklerosierende Encephalomyelit is (Diffuse Sklerose). Arch. Psychiat. Nervenkr., 68, 217-244.

Turkington, R. W., and Stempfel, R. S., Jr. (1966). Adrenocortical atrophy and diffuse cerebral sclerosis (Addison-Schilder's disease). J. Pediat., 69, 406-412. 